\title{
2. Conceptualizing Decentralization and the History of Statehood in the Middle East and North Africa
}

\author{
Roland Sturm and Thomas Demmelhuber
}

Decentralization, "the transfer of rule from the central government level to regional and local levels" (Demmelhuber, Sturm, and Vollmann 2020), has been on the rise globally since the early 1990s (see Figure 1). Decentralization is one among several forms of power-sharing between the center and the regions in a nation-state ${ }^{1}$. It is a broad category which subsumes topdown and bottom-up processes of social, constitutional and cultural change. Its implementation carries a normative quality (see Wibbels 2006, 166): The concept implies improved democratic standards when implemented (see Jones 2009) and it is regularly included in a broad set of indices on the quality of democracy. ${ }^{2}$

These effects of decentralization are difficult to prove as, among others, Treisman $^{3}$ has demonstrated. He argues, "it is hard to reach any general conclusions about whether political - or administrative, or fiscal - decentralization will improve or impair the quality of government and economic performance." (Treisman 2007, 274) ${ }^{4}$ Therefore, any one-size-fits-all prescriptions of decentralization are not particularly helpful (see Hutchcroft 2001, 24). It would moreover be incorrect to assume that the predominance of autocratic regimes in the MENA countries precludes decentralization by definition. On the one hand, there is no rule of thumb for normative judgments. It is moreover of high importance to move beyond the association of authoritarianism with centralization and democracy with decentralization. [...] The process of decentralization may sometimes promote democracy, but it is quite easy to conceive of an "autocratic decentralization" in situations where authority is devolved to authoritarian enclaves at the local level (Hutchcroft 2001, 33).

1 Nation-state is hereby a descriptor of the analytical (national) level and not a normative concept within the notion of Westphalian statehood, see also Tilly (1992).

2 For example, V-Dem Institute (2020).

3 See also, for example, De Vries (2000).

4 See also Kaiser and Ehlert (2009). 
Decentralization can upgrade as well as downgrade and/or challenge authoritarian rule (see Vollmann et al. 2020). On the other hand, despite a consistently high number of resilient autocracies both in the MENA (see Kneuer and Demmelhuber 2021) and worldwide (see Lührmann and Lindberg 2019), decentralization has been in vogue as a political reform initiative for more than three decades. Figure 1, based on data retrieved from the Varieties of Democracy index, illustrates this trend of increasing electoral modes on the local government level in MENA countries and worldwide. The critical juncture of the Arab uprisings led to a further boost in decentralization rhetoric, although decentralization implemented on the ground - as shown in Figure 1 with "local government elected" as proxy indicator - increased only marginally.

Figure 1: Decentralization and elections on the local level over space and time

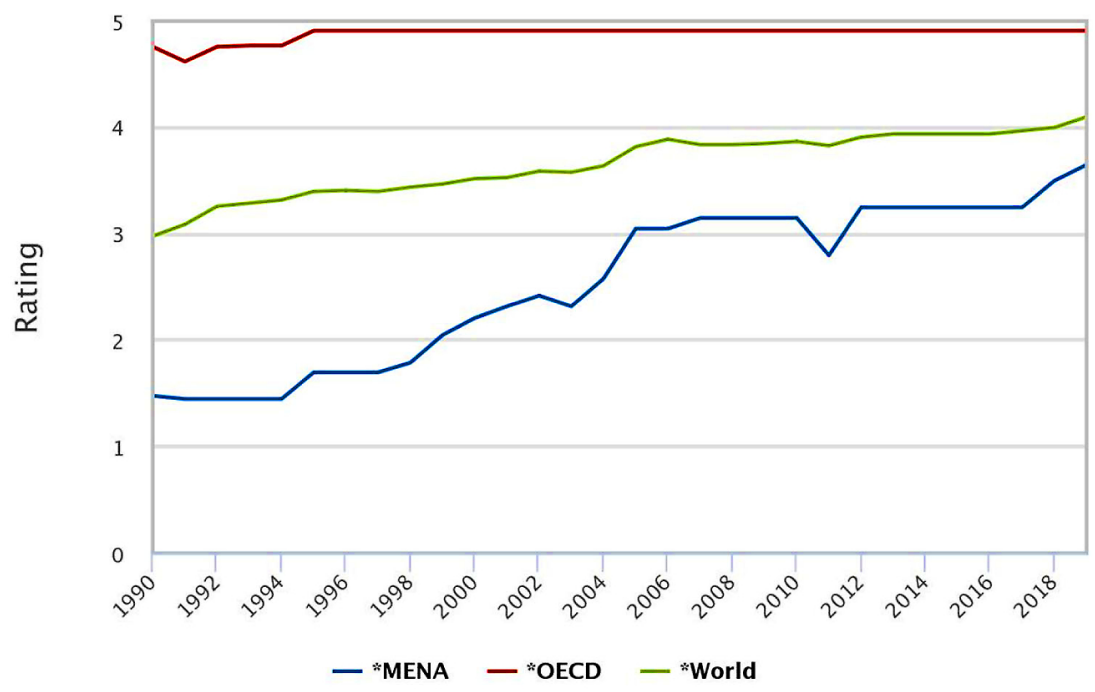

Highcharts.com | V-Dem data version 10.0

V-Dem (2020) coding: 0: Generally, offices at the local level are not elected. 1: Generally, the local executive is elected but not the assembly. 2: Generally, the local assembly is elected but not the executive. 3: Generally, the local executive is elected and there is no assembly. 4: Generally, the local assembly is elected and there is no executive. 5: Generally, the local executive and assembly are elected. 
Varieties of decentralization beyond international donors' hope

What are the triggers for decentralization? What does decentralization stand for in the MENA region? How can we explain variance in decentralization processes? Who are the relevant actors behind decentralization and how can we grasp their motives? Despite substantial research in this field, the question of how to understand the numerous challenges facing decentralization in the MENA region constitutes a gap in research. ${ }^{5}$

The approach we have chosen in this edited volume is empirical, as we do not accept as a normative premise that decentralization matters and we are not concerned whether decentralization or centralization might be the better mode of governance. We go beyond normative assumptions that decentralization is a necessary precondition or even a booster for democratization: Western donors, including the International Monetary Fund (IMF), the World Bank, as well as local civil society activists have been encouraging decentralization reforms for decades. They expected decentralization to enhance local autonomy, democracy, accountability and the overall socioeconomic situation of a country (for this perspective see chapter 6; see also Vollmann et al. 2020). However, one decade after the Arab uprisings began, only Tunisia managed to continue down the bumpy path of democratic consolidation with numerous stress factors still to come (see Demmelhuber 2018).

\section{Where and what is the region in MENA statehood?}

When comparing decentralization efforts we are confronted with an unsolved problem of institutional design. So far, there is no consensus on what constitutes a region in a domestic setting. In MENA countries the definition and denomination is deeply influenced by the colonial/imperial era and the process of state-building that began in the early $20^{\text {th }}$ century. In every state of the world there are subnational tiers of government that are often tied to distinct purposes, such as water or electricity grids. Administrative needs foster administrative decentralization. Any empowerment of a region - even in a limited and/or cosmetic form - has an impact on the policy- and decision-making in a country independent of its regime type.

5 See both for the research base and the still persisting research questions the program on "Governance and Local Development (GLD)" at the Department of Political Science, University of Gothenburg. 
In MENA countries, this kind of empowerment is frequently an informal side effect of decentralization, as our cases demonstrate, rather than a deliberate strategy. This side effect is a conspicuous one. Whether the acceptance of regional approaches legitimates regional governance often depends on resources redistributed (we focus on fiscal policy) and the ability of regions to integrate into the neopatrimonial power games that traverse all levels of subnational government. All regions in MENA countries have in common that they provide an additional stage (in addition to local government) for the struggle between efficiency and participation in governance. Table 1 summarizes the choices for regional policy styles that might develop as a result of this struggle.

Table 1: Regional policy styles

\begin{tabular}{|l|l|l|}
\hline & $\begin{array}{l}\text { Regions with resources and } \\
\text { economic clout }\end{array}$ & $\begin{array}{l}\text { Regions without resources } \\
\text { and weak economies }\end{array}$ \\
\hline Regional identities strong & subsidiarity & partnership \\
\hline Regional identities weak & exploitation & loyalty to the center \\
\hline
\end{tabular}

In our case studies, regional policy styles are less dichotomous than Table 1 seems to suggest. Informal decision-making processes and networks at play help avoid an attack on political dominance of the center, even if identity conflicts or conflicts over resources remain possibilities. However, loyalty to the center is but one factor that defines the relationship between the center and the regional governance level. Further factors include the quality of top-down dominance and the influence of new models of partnerships (e.g. cooptation of local elites for party lists) that may impact electoral contests. Institutional design allows relative flexibility in structuring the future of decentralization. But "central agencies", "top-down models" and "regional agencies" (see Table 2) remain more important than the opportunities a bottom-up decentralization process would provide. It is remarkable how little attention is paid to transactional costs of national and regional governance in the MENA countries, especially when the center expects regions to be more than compliance managers. 
Table 2: Alternatives of institutional design for decentralization (based on Fowler [2020, 715])

\begin{tabular}{|l|l|l|l|l|}
\hline $\begin{array}{l}\text { Institutional } \\
\text { design }\end{array}$ & Agencies & $\begin{array}{l}\text { Coordination } \\
\text { mechanism }\end{array}$ & Advantages & Constraints \\
\hline $\begin{array}{l}\text { Central } \\
\text { agencies }\end{array}$ & State & Policy monopoly & $\begin{array}{l}\text { Minimizes coordi- } \\
\text { nation costs; re- } \\
\text { duces bureaucrat- } \\
\text { ic layers }\end{array}$ & $\begin{array}{l}\text { No access to local ca- } \\
\text { pacities or resources }\end{array}$ \\
\hline Top-down & State; local & $\begin{array}{l}\text { Directed by state } \\
\text { agency; local serves } \\
\text { as state sub-unit }\end{array}$ & $\begin{array}{l}\text { Incorporates local } \\
\text { capacities and re- } \\
\text { sources }\end{array}$ & $\begin{array}{l}\text { Coordination costs; } \\
\text { local agencies are } \\
\text { compliance man- } \\
\text { agers }\end{array}$ \\
\hline Bottom-up & State; local & $\begin{array}{l}\text { Bargaining between } \\
\text { state and local }\end{array}$ & $\begin{array}{l}\text { Incorporates local } \\
\text { capacities and re- } \\
\text { sources }\end{array}$ & $\begin{array}{l}\text { Coordination and } \\
\text { bargaining costs }\end{array}$ \\
\hline $\begin{array}{l}\text { Regional } \\
\text { agencies }\end{array}$ & $\begin{array}{l}\text { State; } \\
\text { regional }\end{array}$ & $\begin{array}{l}\text { Directed by state } \\
\text { agency; some bar- } \\
\text { gaining between } \\
\text { state and regional }\end{array}$ & $\begin{array}{l}\text { Development of } \\
\text { specialized capaci- } \\
\text { ties }\end{array}$ & $\begin{array}{l}\text { Additional layer of } \\
\text { bureaucracy; infor- } \\
\text { mation asymmetries }\end{array}$ \\
\hline $\begin{array}{l}\text { Emergent } \\
\text { governance }\end{array}$ & State; local & Self-organization & Local flexibility & $\begin{array}{l}\text { Economy of scale for } \\
\text { transaction costs }\end{array}$ \\
\hline
\end{tabular}

The narrow definition of efficiency that guides the countries in MENA when they implement decentralization, as well as the countries' tendency to avoid meaningful regional and local participation, become manifest in the high restrictions and limitations to electoral arenas at the local level (see Figure 1). But the lack of regional and local involvement is not a one way-street. Local and regional administrators often see themselves in a tradition of obedience and loyalty toward the center and rarely developed a strong impetus to shape regional and local governance.

\section{Structure matters}

We accept and pay tribute to the fact that governments and parliaments in the MENA region have partially opted for implementing decentralization measures. The methods and means of these efforts often correlate with the history of state-building in MENA since the early $20^{\text {th }}$ century. This includes a colorful mixture of pre-state patterns (in particular going back to the Ottoman era) and external engineering on behalf of European powers during the colonial/imperial era (see Hudson 1977). Historical and contemporary social science research on the MENA region has shown that preand early modern identities, as well as the selection of representatives, were often attached to cities or certain landscapes. For a long time after in- 
dependence, domestic regions and regional identities no longer played a formal role, although regional identities remained in people's minds (see Visser and Stansfield 2008). Local or regional identities were considered obstacles to the development of a national identity and the consolidation of national sovereignty (see Philipp 1994). In the ideologically dominant discourse of nationalism that prevailed for many years, there was a fierce competition between territorial (local) nationalisms of newly established independent states and the narrative of a unifying Arab nationalism. Both preferred a centralist concept of statehood for the sake of forging a nation (see the works of al-Husri; see also Tibi $1990 \mathrm{a} / \mathrm{b}$ ) and defending the nation against external adversaries (in particular after the independence of Israel 1948; Gershoni and Jankowski 1997).

There is a broad consensus in Middle East Political Science research that the personal and often informal exercise of power is of great importance for understanding MENA politics. This implies a certain ad hoc character of state order, which leads to a mosaic structure of societies in the region. For this reason, some state-building processes such as in the Gulf region have even been called "historical accidents" (Anderson 1991, 3). State order is both the result and cause of constant social struggles and negotiation processes. The personal or dynastic character of state rule in the MENA region led to a concentration of power in a few centers, while the center's power and influence over people and territory waned and fragmented as the spatial distance to the center increased (see Herb 1999). Each political order was thus based on the interaction of the center and peripheral groups who defended their autonomy against efforts of the center to control them. The center integrated local groups and created statehood by utilizing traditional pre-state modes of rule, as Hertog $(2011,10)$ vividly illustrates for the case of Saudi Arabia:

The modern Saudi state was created rapidly [...] through the decisions of a few Saudi royals. In this hierarchical, vertically divided hub-andspoke system, the only common denominator has been the central role of the Al Saud ruling family as patrons and controllers of the purse and the only macro-level political force in the kingdom.

Particularly in peripheral regions, there is often a deep-rooted network of autonomous subsystems that has evolved over centuries. Mielke et al. examined this as a dimension of social order in the absence of statehood (see Mielke, Schetter, and Wilde 2011). These structures only partially build on a legal basis. In many cases, they are based on informal claims. The exercise of power is usually legitimized through a ruler's specific personal qualities that allegedly guarantee the continuation of local traditions (see Hertog 
2011). The strong interdependence reproduced in neopatrimonial networks and patronage-based relations, which function as a recognized category of order in the relationship of municipalities, regions, and the national level, can deprive decentralization efforts of their normative goal (such as, for example, dismantling socio-regional center-periphery dichotomies). It is precisely the informality of political and social orders that counteract the aims of decentralization. ${ }^{6}$

In the MENA region, the transfer of sovereignty to lower levels of government based on the principle of subsidiarity (see Table 1) has nowhere taken hold (see Demmelhuber and Sturm 2016). The idea that efficient centralized governance is superior to models of regional empowerment remained unchallenged for a long time. The colonial legacy, the nationbuilding process, and the clustering of autocratic regimes among MENA states were unfavorable conditions for decentralization. This may be one reason why in international comparisons MENA countries are thus far virtually non-existent in databases (see Harguindéguy, Cole, and Pasquier 2019), with the exception of Morocco and Egypt. Our research results (see chapters 4 and 5) will provide a more nuanced picture by taking a closer look into the cases of Morocco, Tunisia, Egypt, and Jordan.

\section{Institutional reform as booster}

Decentralization in the MENA region is first and foremost a strategy of national governments. They respond to the (financial and political) pressure of donor nations or feel forced to accommodate ethnic minorities and/or local elites who are important to securing stability and security as well as economic success. The institutional consequences of decentralization reforms have many aspects. For practical reasons, governments may decide to deconcentrate public administration, that is to say ministries open up branches in a country's periphery or at least implement representation that both monitors and tries to steer regional activities. Lower level public administration may be short-lived regarding details of their tasks and powers. This is a flexible and convenient transmission belt for central government initiatives, but on the downside rigidifies a hierarchical relationship with the regions. A constant threat to the regime is the possibility that reports on regional needs and on resistance regarding central government inter-

6 See, for example, current findings on Tunisia by Yerkes and Muasher (2017). 
ventions are whitewashed to please the upper levels of public administration and the political elite in the capital.

At least in theory, the entrenchment of decentralization in national constitutions is a step forward. Through textualization, legal minimum standards for routes of regional participation come to be. Whether constitutional provisions play a role in national politics in reality is an empirical question. In the MENA region, as in other countries with written constitutions, we can expect many degrees of deviance from the standards and practices a constitution aims to uphold. And yet, constitutional rules allow discussions on the spirit of legal privileges and procedures, both by the judicial branch of government and by the general public. What is more important, written constitutions may legitimize decentralization and may provide a forum for further constitutional change. The essence of decentralization, however, lies not in the constitution itself but in society. It is society that entrenches decentralization and makes it meaningful in practical terms despite being permanently challenged by underlying neopatrimonial networks, as our research on Morocco, Tunisia, Egypt, and Jordan demonstrates. ${ }^{7}$ Wibbels $(2006,167)$ calls the structural consequences of diversity that stem from the forces underpinning institutions rather than from the institutions themselves "institutional endogeneity". Institutional endogeneity strengthens the argument for our bottom-up empirical approach in contrast to the top-down expectations that models of decentralization create. We are, of course, well aware of the paradox inherent to decentralization: Its progress finally depends on the willingness of the center not the wishes of subnational legal entities.

\section{Measuring decentralization}

Because of the absence of federalism in MENA countries (see Mallat $2003)^{8}$, the arena between the national and local level often remains an illdefined category from a constitutional perspective. Here Elazar's concepts of self-rule and shared rule (1987) are helpful, as they move beyond rigid constitutional terminology. They make it possible to center in on the political process of decentralization and the balance or imbalance established

7 For a similar discussion on federalism see Thorlakson (2003).

8 The federal constitution of the Iraq, for example, has no substantial consequences and Iraqi statehood is by definition fundamentally challenged. For a more optimistic view see Mingus (2012). 
between central and local powers. Shared rule in MENA countries is above all informal rule, whereas formal self-rule scarcely exists and/or does little to shift the power balance in nation-states. Genuinely regional tasks are often still de facto in the hands of local officeholders. However, the local level pursues very different priorities and distinct political logics. Moreover, local politics is not necessarily the product of decentralization since it builds on a long political tradition, which in the course of decentralization has been confronted with new political impetus.

In addition to administrative decentralization and regionalism in a nation-state, regions in the Middle East and North Africa can be defined by the decentralization of policies. Constitutionally anchored decentralization is often, but not always, the pre-condition for policy decentralization. National security policies, for example, can develop regional structures without a formal revision of competences in a nation-state. Meaningful decentralization and resulting financial independence is a prerequisite for substantial policy making. But how can this be organized? A number of empirical questions have to be asked: Which level of government collects taxes, how much do they collect, how much autonomy do subnational levels of government have in setting tax policy, and how are revenues shared across levels of government (see Wibbels 2006, 169)? It is said that "country experiences by and large suggest that there is need to supplement the decentralization of spending responsibilities with the assignment of significant sources of revenue to subnational governments." (Lalvani 2002, 25; see also Hankla 2009, 640).

Any budget for the regions in MENA countries can naturally be co-financed by regional sources and/or taxes. The allocation of funds is, however, above all a strategic tool for the center to provide incentives that create loyalty (not least by the access to corruption that a budget makes possi$b^{9}{ }^{9}$ ) and distribute resources to support preferences for regional development as endorsed by the center. Ironically, research has shown that participation of the center in subnational government (shared rule) helps to avoid corruption excesses, which are more prone to occur in situations of local and regional self-rule. There seems to be an agreement in literature that decentralization as such is no panacea for corruption (see Neudorfer and Neudorfer 2015).

Virtually all decentralization indices make use of fiscal variables (see Harguindéguy, Cole, and Pasquier 2019, 12). Budgetary allocations can be block grants or categorical grants, which are meant to improve the effi-

9 As has been shown by Kuenzi and Lambright (2019). 
ciency and effectiveness of policies. Block grants tend to increase the regional and local budgetary autonomy, whereas categorical grants involve the center in subnational decision-making. In Wibbels' $(2006,170)$ view:

The more decentralized governments rely on intergovernmental transfers, the greater the incentive for subnational politicians to engage in the kind of overspending that can threaten the overall economic health of a nation.

This, he suggests, can be avoided by granting subnational spending powers that encourage tax competition and favor less intrusive governments on the local level. As of now, these powers are out of reach for subnational governments in MENA countries. Regional budgets can lead to political gains as well as political power compromises between central and regional elites and/or subordinates. Such budgets function as a seismometer of tectonic changes in the power relationship between the center and the regions.

\section{Empowerment and its limit}

In the MENA region, decentralization may function as a concession to (emerging) rival power centers, be they ethnic strongholds, territorial power centers of oppositional actors, economic hotspots, or (in rare cases) conditions by donors. Decentralization remains flexible and its effects are highly informal. As long as the role of the center is left unchallenged, a wide range of administrative and organizational changes is possible. The changes' success above all depends on efficiency criteria and on their fit with the dominant power relationships in a society. The form and legal characteristics of decentralization arrangements may differ, but they converge when it comes to resources, supporting networks, and the role of the center. For the center decentralization is a governance problem. A more successful and robust steering process and change management is more important than participatory democracy or the empowerment of regional elites.

Empowerment is predominantly only the second step. It follows the creation of preconditions for regional elites to attain relative autonomy. Neopatrimonial networks have a regional dimension, but they do not automatically create regional autonomy. These networks are inclined to support authoritarian political cultures. In these environments, regional decision-makers tend to rely on traditions of obedience and formality. They do not see constitutional or institutional change as opportunity struc- 
ture, but as a new environment for the power games they know. Networks infiltrate formal structures of authority, they penetrate institutions and administrative routines of policymaking (see Hutchcroft 2001, 27). It is therefore problematic to assume as De Vries does, that "local elites do not support decentralized responsibility for issues having national or global causes and consequences." (De Vries 2000, 218). Local elites' tactical value for maintaining neopatrimonial networks is worth more to central elites than the issues at stake. Hence, the scope literature on neopatrimonialism and the role of patronage networks both generally and in the region in particular is as diverging as it is comprehensive. At times the literature even developed a hegemonic character (see Erdmann and Engel 2006; Ruiz de Elvira, Schwarz, and Weipert-Fenner 2018). Its focus was primarily on the central state level, including the respective constellations of actors. The political relevance of neopatrimonial networks in the periphery is admittedly acknowledged, nevertheless, previous research usually leaves the question of the role of patronage networks in processes of decentralization unanswered.

\section{Conceptual roadmap: How to grasp the informal in a formal setting?10}

We argue that decentralization in the MENA region can only be understood by looking at the role of neopatrimonial networks at all levels of government, i.e. the central, regional and local levels. Policies of decentralization are guided, inspired and used for their purposes by informal personal networks. They penetrate the central (national), regional and local levels of government. Decentralization processes, how they emerge and how they function, are hence more than the result of constitutional reforms. The impact of decentralization depends heavily on the degree and quality of informality and its framing by neopatrimonial networks.

We attribute special importance to elite networks at the regional level who are connected with their counterparts at both the central and the local levels of decision-making. We assume that these neopatrimonial networks, because of their strategic position between the national and local level, can have the ability to shape the outcome of decentralization policies. We derive three vital characteristics of governance in the MENA region from the literature: (1) Formal rule is centrally organized but fluid,

10 The conceptual argument is based on Demmelhuber, Sturm, and Vollmann (2020). 
with autonomous social fragments in the periphery. (2) Neopatrimonialism is a basic principle of governance throughout the region. This implies a systematic interplay of formal and informal politics. (3) The integration of research on elite actor networks on the regional and local levels into our research agenda is overdue.

We assume that interactions between formal and informal institutions will change the outcome of decentralization: State authority may for example be impeded by insufficient funding or dependence on regime elites. Mere delegation of administrative tasks can be exploited by sub-national elites and actors and redefined in order to steer policies towards autonomous decision-making. This results from interactions of informal and formal institutions. After their independence in the $20^{\text {th }}$ century, MENA states were centralist states, but statehood in the Westphalian notion of nation-states often remained precarious. Because of arbitrary boundaries and "divide et impera" tactics under colonial rule, the formation of the MENA states began without political unity or (a national) identity of the people. Decentralized structures often served colonial/imperial powers' interest by excluding actors while promoting and fostering other actors on the local level. The centralist regimes of the new states employed a personal or family-based logic of governance, heavily reliant on neopatrimonial networks (see Herb 1999). The citizens' loyalty to the national regimes' rule remained in competition with other strong social ties based on religion, ethnicity or, most importantly, tribalism - especially in the periphery of the MENA states. Formal governance remained wanting in the provinces where a pre-state social order of autonomous sub-entities prevailed. To govern in the MENA periphery, rulers had to work with or against those sub-state patrimonial authorities. In a pivotal contribution on the importance of family and tribe in MENA politics after formal independence, Charrad elaborates on the strategies of the Moroccan, Tunisian and Iraqi leaders to establish their regimes' rule over national and local neopatrimonial networks. She identifies patterns of marginalization and integration (or shifts between those patterns) as strategies of the center when dealing with local networks (see Charrad 2011).

The importance of traditional authorities and institutions in the periphery remains high. Regimes still need to deal with local or regional elites to assert peripheral governance. The importance of personal patron-client networks and the interplay of formal and informal politics for efficient governance results in a high degree of flexibility of neopatrimonial rule in the Middle East and North Africa. It is logical to assume that the same flexibility will be found when looking at decentralization policies. The impact of informal decentralization policies is likely to be even more important 
than legal norms imply. To assess the impact of neopatrimonial networks on the national, regional and local levels of government, we have to identify the political elites involved and their interests in decentralization policies (see chapter 4). Hence, we argue that the neopatrimonial network of elites at the national level is accompanied by neopatrimonial networks on the regional and local levels of a country. The center, or even sectors of the center, can interact with lower-level networks. In some cases they are tightly interwoven with them. For our approach, it is crucial to acknowledge the existence and relevance of neopatrimonial networks on the regional and local levels. We also need to analyze their possible connections with the national level. While direct cooperation or interaction between the regime and the regions has the potential to marginalize the regional level, we assume that this context still is important for a (limited) role of the regions in formal decentralization reforms. Neopatrimonial networks facilitate interactions between the central government and the regional and local levels. It is possible, as we show in this chapter, to identify different kinds of networks and to trace them. First and foremost, regional positional networks are based on the formal status of regional decision-makers. This formal position is always open to constitutional engineering, but above all dependent on the role of informal power bases and informal decision-making. The identification of relevant elite actors and their interactions is the key issue for an explanation of the variance in the outcome of decentralization processes. Previous investigations of elite networks were macro-level studies, primarily interested in the regime's perspective. The thematic focus on decentralization allows for updated elite mapping that integrates actors beyond the center who are politically relevant for decentralization reforms (for methodological reflections, see chapter 4).

\section{Top-down and bottom-up factors of decentralization}

Decentralization is the transfer of rule from the central level to regional and local levels. It is often a deliberate formal process implemented by centralist regimes, but it is nevertheless (1) influenced by informal clientelist and patronage networks in the center, the region and in the municipalities, and (2) does have an impact on the creation and functions of those networks. Decentralization modes encompass the top-down (central) regime decisions and actions as well as bottom-up activities and the feedback of local and regional actors when enabling, using, or circumventing changes of governance. The strategies of MENA rulers since the 1990s gave preference to a top-down (driven by the regime) implementation of decen- 
tralization, mostly - but not only - by establishing or strengthening formal institutions. Another strategy is the endorsement of neoliberal reforms and privatization of local service provision. Instead of increased regional accountability and efficiency, as results of these reforms scholars have observed the strengthening of central state influence due to the elimination of traditional checks and balances (see Bergh 2012; Clark 2018). The seminal approach by Hutchcroft (2001), however, points to the possibility of (informal) bottom-up decentralization as an attempt of local patrimonial networks to fill in the voids left by weak capacities of the central regime. Most comparative studies with a macro-level perspective did not capture this notion of decentralization. Yet it seems of high relevance in the case of MENA regimes, who are generally characterized by a high fragmentation of the centralist regime's capacity in the periphery.

Although formal provisions for decentralization have a strong potential to determine structural and policy outcomes, we expect that for decentralization in the MENA region the impact of informal processes is of even greater importance. Central aspects for the efficacy of decentralization processes are the perceived legitimacy of decentralization and/or people's support, the goals of the involved neopatrimonial networks, and the strength of local and regional actors.

As argued above, we expect that decentralization in MENA is shaped by the interplay of formal and informal institutions and is driven by the relationship of neopatrimonial networks on different levels of governance. Neopatrimonial governance in the MENA region stands for an ongoing struggle of the central government with socio-political fragments in the periphery. Neopatrimonial networks can therefore shape, use or undermine the institutional setting of a given state, depending on their respective goals:

(1) MENA states have witnessed the co-optation of local elites through the central regime, thus circumventing the restrictions of formal institutions. Do actors on the regional political level defend the formal standards of decentralization policies? Or do they align with informal government strategies? The latter is likely to attract formal support and resources by the central government.

(2) Central elites might experience decentralization as a possibility to widen their influence on different political levels or offices. To the central elites, the networks at the lower levels should function as an extension of their spheres of influence. However, the situation may arise that newly empowered regional elites appear as threats to national level networks, which could prove as a barrier to successful cooperation. 
(3) If strong local and regional actors exist, they may strive for greater autonomy by making use of formal decentralized institutions. But if the legal setting of decentralization politics lacks local and/or regional support, or mirrors the patronage networks on the national level, they may try to circumvent such institutions.

\section{Fiscal policy and decentralization}

The undisputed importance of informal institutions in MENA states implies that the evaluation of the normative claims of decentralization can only be a point of departure, a blueprint for officially presented intentions that must be compared with the de facto outcome of the respective reforms. We suggest fiscal policies as a testing kit for the true quality of regional power-sharing. Using fiscal policies as an indicator allows us to trace decentralization. Financial relations between the national and sub-national levels of political systems can serve as an important indicator of the de facto implemented level of decentralization strategies. Fiscal policy leaves its imprint on other policy fields as well. The ability to tax one's population has been described as a regime's extraction capacity. It is a proxy for a regime's capacity to govern (Cheibub 1998; see also Lieberman 2002). This establishes a direct link between taxation and the governability of a political regime. But in the MENA region, tracking taxation may be insufficient to deduce political realities, if it is used as the sole indicator for the capacity to control public finances. This is particularly true for rent economies who do not have a tax-burden, or are dependent on taxes only to a very small degree. The analysis of taxation data and the division of tax revenues between the different levels of the political system provides additional information on central state's capacity to govern, or on the corresponding capacity of sub-national governments. There is some evidence that sub-national institutions occasionally fall short of their potential in tax collection, either because of a lack of administrative efficiency, or even intentionally in order to uphold local support (Harb and Atallah 2014). Another explanation may be a narrow tax base and structural factors (e.g. informal economies). A broader approach to understanding budgetary policies of MENA states is thus necessary (see Lust and Rakner 2018). Local budgets are not interesting per se, but they provide facts that help understand the readiness of central governments to decentralize. Accordingly, a significant change in resource allocations may signal the empowerment or conversely the loss of power - of the subnational level. Local budgets are an indicator of the possible degree of power-sharing. If national gov- 
ernments decentralize fiscal policy and reduce financial oversight, they thereby promote a higher degree of decentralized decision-making processes.

\section{Conclusion}

Decentralization is a vividly discussed topic among populace and governments in many parts of the Middle East and North Africa. International donors such as the IMF or the World Bank, Arab civil society activists and organizations, as well as some researchers have articulated great expectations. But in reality, the outcomes of decentralization reforms and their consequences at the local and regional level are yet unknown or unclear at best. Nonetheless, the topic presents an excellent opportunity to develop a broader and deeper understanding of governance and governability under the condition of neopatrimonialism in MENA countries. Neopatrimonialism is the informal, all-embracing and penetrating feature in the interplay of the central, regional and local levels of the Middle Eastern and North African state. Based on an assessment of the quality and nature of neopatrimonial networks in the MENA region, we identify, track and explain the causes and outcomes of political decentralization. By doing so, we present a more dynamic and elite-driven understanding of decentralization policies in MENA countries. We hereby moreover demonstrate how focusing on the composition, change, and interdependence of neopatrimonial networks relevant for decentralization attempts is a promising alley of research to help explain the variety of outcomes of decentralization reforms. By utilizing fiscal policy and informal financial flows to investigate decentralization in depth, we aim to provide conceptual insights for the study of decentralization worldwide.

\section{References}

Anderson, Lisa. 1991. "Absolutism and the Resilience of Monarchy in the Middle East.” Political Science Quarterly 106 (1): 1-15. doi:10.2307/2152171.

Bergh, Sylvia. 2012. “'Inclusive' Neoliberalism, Local Governance Reforms and the Redeployment of State Power: The Case of the National Initiative for Human Development (INDH) in Morocco.” Mediterranean Politics 17 (3): 410-426. doi: 10.1080/13629395.2012.725304. 
Charrad, Mounira M. 2011. "Central and Local Patrimonialism.” The ANNALS of the American Academy of Political and Social Science 636 (1): 49-68. doi:10.1177/0 002716211401825.

Cheibub, José A. 1998. "Political Regimes and the Extractive Capacity of Governments: Taxation in Democracies and Dictatorships.” World Politics 50 (3): 349376. doi:10.1017/S0043887100012843.

Clark, Janine. 2018. Local Politics in Jordan and Morocco: Strategies of Centralization and Decentralization. New York: Columbia University Press.

De Vries, Michiel S. 2000. "The Rise and Fall of Decentralization: A Comparative Analysis of Arguments and Practices in European Countries.” European Journal of Political Research 38: 193-224. Accessed October 29, 2020. https://link.springer .com/article/10.1023/A:1007149327245.

Demmelhuber, Thomas. 2018. "Die Politische Ordnung in Tunesien und die Beziehungen mit der EU seit 2011: Dezentralisierung als Blaupause?” Accessed October 29, 2020. http://iep-berlin.de/wp-content/uploads/2018/12/demmelhube r.pdf.

Demmelhuber, Thomas, and Roland Sturm. 2016. "Warum gibt es keinen Föderalismus in den arabischen Ländern? Zur Dialektik von Autokratie und dezentraler Herrschaft." In Jabrbuch des Föderalismus 2016, edited by Europäisches Zentrum für Föderalismus-Forschung Tübingen, 165-178. BadenBaden: Nomos.

Demmelhuber, Thomas, Roland Sturm, and Erik Vollmann. 2020. "Decentralization in the Arab World: Conceptualizing the Role of Neopatrimonial Networks." Mediterranean Politics 25 (4): 499-521. doi:10.1080/13629395.2018.15593 91.

Department of Political Science, University of Gothenburg. "Governance and Local Development.” Accessed October 29, 2020. http://gld.gu.se.

Elazar, Daniel J. 1987. Exploring Federalism, Tuscaloosa. Alabama: The University of Alabama Press.

Erdmann, Gero, and Ulf Engel. 2006. "Neopatrimonialism Revisited: Beyond a Catch-All Concept: GIGA Working Paper No 16.”. Hamburg: GIGA.

Fowler, Luke. 2020. "Governance, Federalism and Organizing Institutions to Manage Complex Problems.” Public Administration 98 (3): 713-729. doi:10.1111/ padm.12638.

Gershoni, Israel, and James P. Jankowski, eds. 1997. Rethinking Nationalism in the Arab Middle East. New York: Columbia University Press.

Hankla, Charles R. 2009. "When is Fiscal Decentralization Good for Governance?" Publius: The Journal of Federalism 39 (4): 632-650. doi:10.1093/publius/pjn034.

Harb, Mona, and Sami Atallah. 2014. "Decentralization in the Arab World must be Strengthened to Provide Better Services.” LCPS Policy Brief (11). Accessed October 30, 2020. http://www.lcps-lebanon.org/publications/1401092788-policy_brie f_11_lcps.pdf. 
Harguindéguy, Jean-Baptiste P., Alistair Cole, and Romain Pasquier. 2019. "The Variety of Decentralization Indexes: A Review of the Literature.” Regional \& Federal Studies. doi:10.1080/13597566.2019.1566126.

Herb, Michael. 1999. All in the Family: Absolutism, Revolution and Democracy in the Middle Eastern Monarchies. New York: State of University of New York Press.

Hertog, Steffen. 2011. Princes, Brokers, and Bureaucrats: Oil and the State in Saudi Arabia. Ithaca, London: Cornell University Press.

Hudson, Michael C. 1977. Arab Politics: The Search for Legitimacy. New Haven: Yale University Press.

Hutchcroft, Paul D. 2001. "Centralization and Decentralization in Administration and Politics: Assessing Territorial Dimensions of Authority and Power." Governance 14 (1): 23-53. doi:10.1111/0952-1895.00150.

Jones, Erik. 2009. "The Architecture of Government: Rethinking Political Decentralization.” Parliamentary Affairs 62 (4): 691-697. doi:10.1093/pa/gsp018.

Kaiser, André, and Niels Ehlert. 2009. "Federalism. Decentralisation, and MacroEconomic Performance.” In Parlamente, Agendasetzung und Vetospieler: Festschrift Für Herbert Döring, edited by Steffen Ganghof, Christoph Hönnige, and Christian Stecher, 69-92. Wiesbaden: VS Verlag.

Kneuer, Marianne, and Thomas Demmelhuber. 2021. Authoritarian Gravity Centers: A Cross-Regional Study of Authoritarian Promotion and Diffusion. Conceptualising Comparative Politics: Polities, Peoples, and Markets 11. New York, NY: Routledge.

Kuenzi, Michelle T., and Gina M. S. Lambright. 2019. "Decentralization, Executive Selection, and Citizen Views on the Quality of Local Governance in African Countries." Publius: The Journal of Federalism 49 (2): 221-249. doi:10.1093/ publius/pjy031.

Lalvani, Mala. 2002. "Can Decentralization Limit Government Growth? A Test of the Leviathan Hypothesis for the Indian Federation." Publius: The Journal of Federalism 32 (3): 25-45. Accessed October 30, 2020. https://www.jstor.org/stable 13330965 .

Lieberman, Evan S. 2002. "Taxation Data as Indicators of State-Society Relations: Possibilities and Pitfalls in Cross-National Research.” Studies in Comparative International Development 36 (4): 89-115. doi:10.1007/BF02686334.

Lührmann, Anna, and Staffan I. Lindberg. 2019. "A Third Wave of Autocratization is here: What is New About it?" Democratization 26 (7): 1095-1113. doi:10.1080/13510347.2019.1582029.

Lust, Ellen, and Lise Rakner. 2018. "The Other Side of Taxation: Extraction and Social Institutions in the Developing World.” Annual Review of Political Science 21 (1): 277-294. doi:10.1146/annurev-polisci-042716-102149.

Mallat, Chibli. 2003. "Federalism in the Middle East and Europe." Case Western Reserve Journal of International Law 35 (1): 1-14.

Mielke, Katja, Conrad Schetter, and Andreas Wilde. 2011. "Dimensions of Social Order: Empirical Fact, Analytical Framework and Boundary Concept.” Accessed October 30, 2020. http://hdl.handle.net/10419/88405. 
Mingus, Matthew S. 2012. "Progress and Challenges with Iraq's Multilevel Governance." Public Administration Review 72 (5): 678-686. doi:10.111/j.1540-6210.201 2.02538.x.

Neudorfer, Benjamin, and Natascha S. Neudorfer. 2015. "Decentralization and Political Corruption: Disaggregating Regional Authority.” Publius: The Journal of Federalism 45 (1): 24-50. doi:10.1093/publius/pju035.

Philipp, Thomas. 1994. "Nationale Einheit und Politische Mehrstaatlichkeit der Araber in der Gegenwart.” In Nationalismus im Mittelmeerraum, edited by HansJürgen Lüsebrink, 114-129. Passau: Passiva.

Ruiz de Elvira, Laura, Christoph H. Schwarz, and Irene Weipert-Fenner. 2018. Clientelism and Patronage in the Middle East and North Africa: Networks of Dependency. Routledge Studies in Middle Eastern Democratization and Government. Milton: Routledge. https:/ebookcentral.proquest.com/lib/gbv/detail.actio n?docID=5453462.

Thorlakson, Lori. 2003. "Comparing Federal Institutions: Power and Representation in Six Federations." West European Politics 26 (2): 1-22. doi:10.1080/0140238 0512331341081.

Tibi, Bassam. 1990a. Arab Nationalism: A Critical Enquiry. 2nd ed. Edited by Marion Farouk-Sluglett and Peter Sluglett. London: Palgrave Macmillan.

Tibi, Bassam. 1990b. "The Foundations of Sati“ Al-Husri's Political Theory.” In Arab Nationalism: A Critical Enquiry, edited by Marion Farouk-Sluglett and Peter Sluglett. 2nd ed., 125-141. London: Palgrave Macmillan.

Tilly, Charles. 1992. Coercion, Capital, and European States, AD 990 - 1992. Cambridge, Mass.: Blackwell.

Treisman, Daniel. 2007. The Architecture of Government: Rethinking Political Decentralization. Cambridge Studies in Comparative Politics. Cambridge: Cambridge University Press.

V-Dem Institute. 2020. “Global Standards, Local Knowledge.” Accessed October 29, 2020. https:/www.v-dem.net/en/.

Visser, Reidar, and Gareth Stansfield. 2008. Iraq of its Regions: Cornerstone of a Federal Democracy? London: Hurst.

Vollmann, Erik, Miriam Bohn, Roland Sturm, and Thomas Demmelhuber. 2020. "Decentralisation as Authoritarian Upgrading? Evidence from Jordan and Morocco." The Journal of North African Studies, 1-32. doi:10.1080/13629387.2020.17 87837.

Wibbels, Erik. 2006. "Madison in Baghdad? Decentralization and Federalism in Comparative Politics.” Annual Review of Political Science 9 (1): 165-188. doi:10.1146/annurev.polisci.9.062404.170504.

Yerkes, Sarah, and Marwan Muasher. 2017. “Tunisia's Corruption Contagion: A Transition at Risk.” Accessed October 30, 2020. https:/carnegieendowment.org/ 2017/10/25/tunisia-s-corruption-contagion-transition-at-risk-pub-73522. 
